\title{
Effects of Dobutamine Infusion in Dorsally Recumbent Isoflurane-Anesthetized Horses
}

\author{
Yutaka MIZUNO ${ }^{1}$, Hiroko AIDA ${ }^{1 *}$, and Toru FUJINAGA ${ }^{2}$ \\ ${ }^{1}$ Equine Research Institute, Japan Racing Association, 5-27-7 Tsurumaki, Setagaya-ku, Tokyo 154 and \\ ${ }^{2}$ Department of Veterinary Surgery, Faculty of Veterinary Medicine, Hokkaido University, Sapporo 060, \\ Japan \\ * Present address: Mizuno, Y., Miho Training Center, Japan Racing Association, 2500-2 Mikoma, \\ Miho-mura, Inashiki-gun, Ibaraki 300-04, Japan
}

\begin{abstract}
Sequential changes in the heart rate (HR), cardiac output (CO) and arterial blood pressure $(A B P)$ were compared in dorsally recumbent isoflurane-anesthetized horses with and without dobutamine infusion. The mean ABP and CO in horses given dobutamine increased to 71.7 $\mathrm{mmHg}$ and $89.7 \mathrm{ml} / \mathrm{kg} / \mathrm{min}$, respectively, and were significantly higher than the values in the group not given dobutamine. And there were no signs of arrhythmia in the dobutamine-treated group. The mean dobutamine administration rate was $0.86 \pm 0.3 \mu \mathrm{g} / \mathrm{kg} / \mathrm{min}$. The results show that dobutamine infusion enhances cardiovascular function in dorsally recumbent horses anesthetized with isofurane.
\end{abstract}

Key words: cardiovascular response, dobutamine, dorsally recumbent, horse, isoflurane

J. Equine Sci. Vol. 5 No. 3

pp. 87-94, 1994
The dorsal recumbency is used in horses during abdominal surgery and arthroscopic surgery performed for the treatment of chip fractures of the carpal or fetlock joints. The risks arising from depressed respiratory and circulatory function in this position in horses under inhalation anesthesia are well known [8, 9, 27].

Intermittent positive pressure ventilation is a useful method for reducing the hypoxemia that occurs in dorsally recumbent horses and has improved respiratory safety during surgery carried out on in this position [17]. However, it has been demonstrated that controlled ventilation reduces cardiac output in anesthetized horses [19].

After general anesthesia in horses, difficulty in standing and lameness ascribed to nerve or muscle damage caused by ischemia have been reported $[10,14,23,24]$. The use of isoflurane instead of halothane has been observed to reduce anestheticinduced circulatory depression [5, 26], although

This article was submitted August 12, 1994, and was accepted November 21, 1994.

*corresponding author. this has been demonstrated only in laterally recumbent horses.

Dobutamine is a catecholamine and has a positive inotropic effect which reverses hypotension in man [30, 31], dogs [32, 33] and horses [4, 28]. It is a selective $\beta_{1}$ stimulant at low to moderate infusion rate. At higher infusion rates, the drug becomes both a mild $\beta_{2}$ agonist and mild $\alpha$ agonist [3]. The studies in horses have described the effects of dobutamine in lateral recumbency under halothane anesthesia, but there are no reports to demonstrate its effects during anesthesia with other inhaled agents in dorsally recumbent horses.

The purpose of the present study was to compare the sequential changes in heart rate (HR), cardiac output (CO), arterial blood pressure (ABP), and urine volume which occurred in dorsally recumbent horses during isoflurane anesthesia alone and with dobutamine infusion. 


\section{Materials and Methods}

Horses: Ten experiments were performed on 6 Thoroughbred and 2 Anglo-Arabian mares, aged 3 to 7 years (mean, $3.6 \pm 1.3$ years), in good health and weighing 445 to $495 \mathrm{~kg}$ (mean, $468.8 \pm 15.0$ $\mathrm{kg}$ ). The horses were randomly assigned to 2 groups of 5 and were given isoflurane only (ND group) or isoflurane and dobutamine (D group). When a horse was used in more than one experiment, the second was performed after an interval of at least one month. Food, but not water, was withheld for $12 \mathrm{hr}$ before each experiment.

Methods of anesthesia: Intravenous (IV) injections (into the left jugular vein via an $18 \mathrm{G}$ catheter) of $1.0 \mathrm{mg} / \mathrm{kg}$ xylazine and $0.01 \mathrm{mg} / \mathrm{kg}$ midazolam were given as premedication, followed by 2.5 $\mathrm{mg} / \mathrm{kg}$ ketamine hydrochloride (given as a bolus) for induction of anesthesia. The horses were placed in a laterally recumbent position and intubated endotracheally, then placed in the dorsal position on a padded surgical table.

Anesthesia was maintained with isoflurane in oxygen delivered by a Fluotec 3 vaporizer (oxygen flow rate, $5 \mathrm{l} / \mathrm{min}$ ). A semi-closed large animal anesthetic system (LAVC 2000, J.D. Medical, Phoenix, USA) with a pressure-limited respirator (Mark 7, Bard, Palm Springs, USA) was used to produce intermittent positive pressure ventilation.

The level of anesthesia was maintained at plane two of the third stage, during which the palpebral reflex and nystagmus completely disappeared. The duration of anesthesia was $120 \mathrm{~min}$.

The horses were allowed to breathe spontaneously for 20 min after the onset of inhalation anesthesia, after which the ventilation mode was changed to controlled ventilation. The endinspiratory airway pressure and respiratory rate were adjusted to 20 to $24 \mathrm{cmH}_{2} \mathrm{O}$ and 6 to 8 breaths/min respectively, so that the arterial carbon dioxide tension $\left(\mathrm{PaO}_{2}\right)$ was maintained between 45 and $55 \mathrm{mmHg}$ and the arterial oxygen tension $\left(\mathrm{PaO}_{2}\right)$ remained in excess of $200 \mathrm{mmHg}$. Lactated Ringer's solution was infused (IV) at about $8 \mathrm{ml} / \mathrm{kg} / \mathrm{hr}$ throughout each experiment.

Dobutamine infusion: The horses in group D received an infusion (IV) of dobutamine (Dobutorex, Shionogi, Tokyo) beginning $32 \mathrm{~min}$ after the onset of inhalation anesthesia. Dobutamine
(100 mg) was dissolved in $500 \mathrm{ml}$ saline solution and administered using an infusion pump (IVAC, Sandiego USA) at a dose of 0.5 to $2.0 \mu \mathrm{g} / \mathrm{kg} / \mathrm{min}$ to maintain the mean arterial blood pressure (MABP) at $70 \mathrm{mmHg}$.

Determinations: The end-expiratory isoflurane concentration (EIC), respiratory rate (RR), electrocardiogram (ECG), HR, ABP, right atrial pressure (RAP), pulmonary arterial pressure (PAP), arterial blood $\mathrm{pH}$ and gases, $\mathrm{CO}$, and urine volume were determined before anesthesia, 15, 30, 45, 60, 75, 90,105 , and 120 min after the onset of inhalation anesthesia, and $180 \mathrm{~min}$ after recovery (standing).

The EICs in expired samples, collected at the $\mathrm{Y}$-piece near the endotracheal tube connection, were measured with a concentration meter $(\mathrm{WH}$ 2512, Bulel Care, Tokyo).

The ABP was measured using a catheter placed in the facial artery at the point of the incisura mandubulae, the RAP was measured using a catheter placed in the right atrium, and the PAP was measured using a Swan-Ganz catheter placed in the pulmonary artery. Each catheter was connected to a calibrated pressure transducer and the pressures were recorded on a polygraph (M 1094A, YHP, Tokyo) which also recorded the ECG, HR, and RR. The zero reference pressure was measured at the level of the scapulohumeral joint (the right atrium) of the standing dorsally recumbent horse.

The CO was determined by the thermodilution method [20] using a precision thermal dilution cardiac output computer (M1012A, YHP). The horse stood in the stock, and two $8 \mathrm{~F}$ introducers were inserted into the left jugular vein, one on the upper and one on the lower side of the neck. The catheter used for injecting drugs was introduced into the vein through the upper side of the introducer and positioned in the right atrium, and the one used for temperature measurement was introduced into the vein through the lower side of the introducer and positioned in the pulmonary artery. The injection indicator was $35 \mathrm{ml} 5 \%$ glucose. The bottle containing this was kept in iced water and its temperature was maintained at $0^{\circ} \mathrm{C}$. The IV glucose infusion was administered over 2 sec using an autoinjector (Nemoto Kyorindo, Tokyo). Three CO measurements were determined at 2-min intervals around prearranged measurement times during anesthesia, and the 
final $\mathrm{CO}$ values for each time point were expressed as the means of the 3 determinations.

Prior to anesthesia, with each mare standing, a urinary catheter was placed into the bladder via the urethra to empty it of urine. A balloon catheter was then placed into the bladder. Urine was collected in a calibrated cylinder and its volume determined during anesthesia.

The total peripheral resistance (TPR) was calculated using the RAP, HR, and MABP recordings and determinations obtained during the study.

Statistical analysis: The means and standard deviations of the values obtained at each measurement time in each group of 5 horses were calculated. Significance of differences between the values was evaluated using the Mann Whitney U test. Differences at $\mathrm{P}<0.05$ were considered significant.

\section{Results}

No abnormal responses requiring treatment occurred during or after anesthesia in any of the horses. All the horses breathed unassisted within $10 \mathrm{~min}$ and stood 25 to $45 \mathrm{~min}$ after discontinuation of anesthetic. The mean volumes of lactated Ringer's solution administered in the D and ND groups were $9.1 \pm 0.2$ and $8.5 \pm 0.5 \mathrm{ml} / \mathrm{kg} / \mathrm{hr}$, respectively; these values were not significantly different. Mean dobutamine infusion rates are shown in Table 1. The infusion rate was highest in Horse No. $3(1.23 \mu \mathrm{g} / \mathrm{kg} / \mathrm{min})$. The MABP between $65.4 \mathrm{mmHg}$ and $71.7 \mathrm{mmHg}$ were achieved using a mean dobutamine infusion rate (from 5 horses) of $0.86 \mu \mathrm{g} / \mathrm{kg} / \mathrm{min}$.

The sequential EIC, HR, and RR, changes are shown in Table 2. The EIC required to maintain anesthesia was 1.4 to $1.9 \%$ in both groups, and no significant differences were observed. The HR in the $\mathrm{D}$ group was lowest ( 27.0 beats $/ \mathrm{min})$ after 45 min of anesthesia and differed significantly from that in the ND group. There were no signs of arrhythmia such as AV block during infusion of dobutamine. The RR in both groups decreased to below the preanesthetic value in response to inhalation anesthesia during spontaneous ventilation, but constant values of 6.5 to 8.4 breaths $/ \mathrm{min}$ were maintained during controlled ventilation.

The sequential changes in ABP, RAP, and PAP
Table 1. Mean dose of dobutamine in isoflurane-anesthetized horses

\begin{tabular}{cc}
\hline $\begin{array}{c}\text { Horse } \\
\text { No. }\end{array}$ & $\begin{array}{c}\text { Dobutamine } \\
(\mu \mathrm{g} / \mathrm{kg} / \mathrm{min})\end{array}$ \\
\hline 1 & 0.93 \\
2 & 0.63 \\
3 & 1.23 \\
4 & 0.99 \\
5 & 0.51 \\
\hline Mean & 0.86 \\
SD & 0.3 \\
\hline
\end{tabular}

are shown in Table 3 , and those in the MABP are presented in Fig. 1. The MABP in the D group was lowest $(40.3 \mathrm{mmHg})$ after $30 \mathrm{~min}$ then increased to between 65.4 and $71.7 \mathrm{mmHg}$ in response to the dobutamine infusion. The values differed significantly from those in the ND group after 45, 60, 75 , and $90 \mathrm{~min}$. The MABP in the ND group remained between 44.3 and $54.6 \mathrm{mmHg}$ after 45 min.

The mean PAP in the $\mathrm{D}$ group increased after infusion of dobutamine and was significantly higher than that in the ND group after $60 \mathrm{~min}$. The mean RAP values did not differ significantly between groups.

The CO per kg body weight, stroke volume, TPR, and urine volumes are shown in Table 4. CO and stroke volume results are also presented in Fig. 1. The CO of group D decreased progressively up to $30 \mathrm{~min}$ then increased with time in response to the dobutamine infusion until it reached or exceeded the preanesthetic level. These values were then maintained. The $\mathrm{CO}$ in the ND group decreased in a time-related manner. The lowest value reached was $39.5 \mathrm{ml} / \mathrm{kg} / \mathrm{min}$ after $120 \mathrm{~min}$, which represented $51.4 \%$ of the preanesthetic value. Significant differences between the COs in the two groups were noted after $60 \mathrm{~min}$ or more, and between the stroke volumes after $45 \mathrm{~min}$ or more of anesthesia. The stroke volume changes in both groups paralleled to those in CO.

The TPR in the $D$ group fluctuated. The TPR in the ND group decreased up to $45 \mathrm{~min}$ then increased slightly with time to reach in excess of $200 \mathrm{dyn} \cdot \mathrm{sec} / \mathrm{cm}^{5}$. The values in the $\mathrm{D}$ groups remained consistently lower than those in the ND group after $75 \mathrm{~min}$ or longer of anesthesia.

The urine volumes in the $\mathrm{D}$ group were higher than those in the ND group during anesthesia and 
Table 2. Mean values for expired isoflurane concentration (EIC), heart rate (HR), and respiratory rate (RR) in dorsally recumbent isoflurane-anesthetized horses with dobutamine (D) and without dobutamine (ND) infusion groups

\begin{tabular}{|c|c|c|c|c|c|c|c|c|c|c|c|}
\hline \multirow[t]{2}{*}{ Variables } & \multirow[t]{2}{*}{ Group } & \multirow{2}{*}{$\begin{array}{c}\text { Pre- } \\
\text { anesthesia }\end{array}$} & \multicolumn{8}{|c|}{ Time during anesthesia (min) } & \multirow{2}{*}{$\begin{array}{l}\text { At } 180 \mathrm{~min} \\
\text { after recovery } \\
\text { from anes- } \\
\text { thesia }\end{array}$} \\
\hline & & & $15^{\mathrm{a})}$ & $30^{\mathrm{b})}$ & 45 & 60 & 75 & 90 & 105 & 120 & \\
\hline \multirow[t]{2}{*}{$\begin{array}{l}\text { EIC } \\
(\%)\end{array}$} & $\mathrm{D}$ & $\underline{-}^{c}$ & $\begin{array}{l}1.6^{\mathrm{d})} \\
0.3^{\mathrm{e})}\end{array}$ & $\begin{array}{l}1.7 \\
0.1\end{array}$ & $\begin{array}{l}1.5 \\
0.2\end{array}$ & $\begin{array}{l}1.5 \\
0.2\end{array}$ & $\begin{array}{l}1.6 \\
0.3\end{array}$ & $\begin{array}{l}1.7 \\
0.1\end{array}$ & $\begin{array}{l}1.8 \\
0.2\end{array}$ & $\begin{array}{l}1.8 \\
0.1\end{array}$ & - \\
\hline & ND & - & $\begin{array}{l}1.9 \\
0.2\end{array}$ & $\begin{array}{l}1.4 \\
0.3\end{array}$ & $\begin{array}{l}1.5 \\
0.5\end{array}$ & $\begin{array}{l}1.5 \\
0.5\end{array}$ & $\begin{array}{l}1.7 \\
0.2\end{array}$ & $\begin{array}{l}1.7 \\
0.3\end{array}$ & $\begin{array}{l}1.8 \\
0.2\end{array}$ & $\begin{array}{l}1.8 \\
0.1\end{array}$ & - \\
\hline $\begin{array}{l}\text { HR } \\
\text { (beat/min) }\end{array}$ & $\begin{array}{l}\mathrm{D} \\
\mathrm{ND}\end{array}$ & $\begin{array}{r}31.6 \\
3.6 \\
35.4 \\
3.1\end{array}$ & $\begin{array}{r}31.0 \\
5.0 \\
34.8 \\
2.5\end{array}$ & $\begin{array}{r}34.0 \\
3.0 \\
36.8 \\
1.9\end{array}$ & $\begin{array}{c}27.0^{*} \\
1.8 \\
36.3 \\
2.4\end{array}$ & $\begin{array}{r}34.6 \\
10.0 \\
36.3 \\
2.2\end{array}$ & $\begin{array}{r}36.4 \\
8.1 \\
33.8 \\
2.6\end{array}$ & $\begin{array}{r}38.2 \\
6.2 \\
32.8 \\
2.6\end{array}$ & $\begin{array}{r}36.6 \\
5.0 \\
32.0 \\
2.9\end{array}$ & $\begin{array}{r}36.2 \\
4.3 \\
31.4 \\
2.1\end{array}$ & $\begin{array}{r}35.3 \\
4.3 \\
33.8 \\
3.9\end{array}$ \\
\hline \multirow[t]{2}{*}{$\begin{array}{l}\text { RR } \\
\text { (breat/min) }\end{array}$} & $\mathrm{D}$ & $\begin{array}{r}15.7 \\
2.1\end{array}$ & $\begin{array}{l}6.5 \\
1.9\end{array}$ & $\begin{array}{l}6.8 \\
1.5\end{array}$ & $\begin{array}{l}6.5 \\
1.0\end{array}$ & $\begin{array}{l}7.0 \\
0.8\end{array}$ & $\begin{array}{l}7.5 \\
0.6\end{array}$ & $\begin{array}{l}7.5 \\
0.6\end{array}$ & $\begin{array}{l}8.0 \\
0.8\end{array}$ & $\begin{array}{l}7.0 \\
1.6\end{array}$ & $\begin{array}{r}15.0 \\
3.0\end{array}$ \\
\hline & ND & $\begin{array}{r}13.0 \\
1.2\end{array}$ & $\begin{array}{l}4.4 \\
1.1\end{array}$ & $\begin{array}{l}7.6 \\
0.9\end{array}$ & $\begin{array}{l}7.8 \\
0.8\end{array}$ & $\begin{array}{l}7.6 \\
1.1\end{array}$ & $\begin{array}{l}8.0 \\
0.7\end{array}$ & $\begin{array}{l}8.0 \\
0.7\end{array}$ & $\begin{array}{l}8.2 \\
1.3\end{array}$ & $\begin{array}{l}8.4 \\
0.9\end{array}$ & $\begin{array}{r}15.5 \\
2.6\end{array}$ \\
\hline
\end{tabular}

a) Spontaneous ventilation. b) Dobutamine infusion started after 30 minutes measurement. c) Not inspired. d) Data are expressed as mean. e) Data are expressed as standard deviation. *Significant difference between D and ND groups, $\mathrm{P}<0.05$.

Table 3. Mean values for systolic arterial blood pressure (SABP), diastolic arterial blood pressure (DABP), mean arterial blood pressure (MABP), mean pulmonary artery pressure (MPAP), and mean right atrial pressure (MRAP) in dorsally recumbent isoflurane-anesthetized horses with dobutamine (D) and without dobutamine (ND) infusion groups

\begin{tabular}{|c|c|c|c|c|c|c|c|c|c|c|c|}
\hline \multirow[t]{2}{*}{ Variables } & \multirow[t]{2}{*}{ Group } & \multirow{2}{*}{$\begin{array}{c}\text { Pre- } \\
\text { anesthesia }\end{array}$} & \multicolumn{8}{|c|}{ Time during anesthesia (min) } & \multirow{2}{*}{$\begin{array}{c}\text { At } 180 \text { min } \\
\text { after recovery } \\
\text { from anes- } \\
\text { thesia }\end{array}$} \\
\hline & & & $15^{\text {a) }}$ & $30^{\mathrm{b})}$ & 45 & 60 & 75 & 90 & 105 & 120 & \\
\hline \multirow{4}{*}{$\begin{array}{l}\text { SABP } \\
(\mathrm{mmHg})\end{array}$} & $\mathrm{D}$ & -c) & $98.4^{\mathrm{d})}$ & 58.7 & $99.8 *$ & $96.0^{*}$ & $99.2^{*}$ & $94.3^{*}$ & 94.7 & $91.7 *$ & 134.0 \\
\hline & & - & $10.0^{\mathrm{e})}$ & 10.5 & 8.9 & 10.7 & 9.0 & 9.6 & 12.7 & 8.1 & 7.0 \\
\hline & ND & - & 96.2 & 66.8 & 65.3 & 65.8 & 73.0 & 73.3 & 76.0 & 74.0 & 146.3 \\
\hline & & - & 7.0 & 9.6 & 6.0 & 9.4 & 9.5 & 6.5 & 7.1 & 6.0 & 11.1 \\
\hline \multirow{4}{*}{$\begin{array}{l}\text { DABP } \\
\quad(\mathrm{mmHg})\end{array}$} & $\mathrm{D}$ & - & 60.8 & 28.3 & $49.2^{*}$ & $48.8^{*}$ & $54.5^{*}$ & $52.7 *$ & 56.7 & 53.0 & 88.3 \\
\hline & & - & 10.7 & 7.8 & 8.1 & 5.0 & 7.7 & 6.7 & 6.8 & 8.9 & 2.3 \\
\hline & ND & - & 56.6 & 34.0 & 33.0 & 33.3 & 37.5 & 39.3 & 42.4 & 41.8 & 96.8 \\
\hline & & - & 8.3 & 5.7 & 3.6 & 6.0 & 4.4 & 5.2 & 5.3 & 5.4 & 6.3 \\
\hline \multirow{4}{*}{$\begin{array}{l}\text { MABP } \\
\quad(\mathrm{mmHg})\end{array}$} & $\mathrm{D}$ & - & 72.8 & 40.3 & $66.0^{*}$ & $65.4^{*}$ & $67.2 *$ & $68.7^{*}$ & 71.7 & 68.0 & 104.0 \\
\hline & & - & 11.3 & 9.7 & 9.5 & 5.3 & 10.5 & 5.9 & 8.5 & 8.9 & 0.0 \\
\hline & ND & - & 71.6 & 46.0 & 44.3 & 49.0 & 50.0 & 51.8 & 54.6 & 52.6 & 115.0 \\
\hline & & - & 8.9 & 7.1 & 4.3 & 7.6 & 6.0 & 6.0 & 6.1 & 5.9 & 7.2 \\
\hline \multirow{4}{*}{$\begin{array}{l}\text { MPAP } \\
\quad(\mathrm{mmHg})\end{array}$} & $\mathrm{D}$ & 25.6 & 8.2 & 6.5 & 11.2 & $13.6^{*}$ & 11.8 & 12.0 & 9.2 & 9.6 & 15.8 \\
\hline & & 2.9 & 6.5 & 0.7 & 5.7 & 4.7 & 5.3 & 7.0 & 7.0 & 6.9 & 4.2 \\
\hline & ND & 21.2 & 9.2 & 5.4 & 3.5 & 3.8 & 3.5 & 2.8 & 4.0 & 5.0 & 17.0 \\
\hline & & 6.3 & 8.3 & 6.6 & 6.0 & 7.1 & 5.9 & 5.9 & 6.2 & 4.2 & 9.6 \\
\hline \multirow{4}{*}{$\begin{array}{l}\text { MRAP } \\
\quad(\mathrm{mmHg})\end{array}$} & D & 11.0 & -2.8 & -2.4 & 0.6 & 1.4 & 1.8 & 0.3 & 0.0 & 0.7 & 7.0 \\
\hline & & 2.2 & 3.6 & 3.5 & 4.0 & 3.0 & 1.0 & 1.5 & 2.6 & 2.9 & 2.6 \\
\hline & ND & 9.3 & -1.2 & -2.6 & -2.3 & -1.8 & -2.3 & -1.8 & -1.2 & 0.2 & 8.7 \\
\hline & & 2.9 & 2.4 & 2.9 & 3.1 & 2.9 & 3.4 & 3.0 & 3.4 & 2.0 & 3.1 \\
\hline
\end{tabular}

a) Spontaneous ventilation. b) Dobutamine infusion started after 30 minutes measurement. c) Not done. d) Data are expressed as mean. e) Data are expressed as standard deviation. ${ }^{*}$ Significant difference between D and ND groups, $\mathrm{P}<0.05$. 
Table 4. Mean values for cardiac output per body weight (CO/kg), stroke volume (SV), total peripheral resistance (TPR), and urine volume (UV) in dorsally recumbent isoflurane-anesthetized horses with dobutamine (D) and without dobutamine (ND) infusion groups

\begin{tabular}{|c|c|c|c|c|c|c|c|c|c|c|c|}
\hline \multirow[t]{2}{*}{ Variables } & \multirow[t]{2}{*}{ Group } & \multirow{2}{*}{$\begin{array}{c}\text { Pre- } \\
\text { anesthesia }\end{array}$} & \multicolumn{8}{|c|}{ Time during anesthesia (min) } & \multirow{2}{*}{$\begin{array}{c}\text { At } 180 \mathrm{~min} \\
\text { after recovery } \\
\text { from anes } \\
\text { thesia }\end{array}$} \\
\hline & & & $15^{\mathrm{a})}$ & $30^{\mathrm{b})}$ & 45 & 60 & 75 & 90 & 105 & 120 & \\
\hline $\begin{array}{l}\mathrm{CO} / \mathrm{kg} \\
(\mathrm{ml} / \mathrm{min} / \mathrm{kg})\end{array}$ & $\begin{array}{l}\text { D } \\
\text { ND }\end{array}$ & $\begin{array}{c}71.8^{\mathrm{c})} \\
5.5^{\mathrm{d})} \\
76.6 \\
8.5\end{array}$ & $\begin{array}{r}62.9 \\
5.7 \\
69.9 \\
21.8\end{array}$ & $\begin{array}{r}58.2 \\
9.9 \\
63.9 \\
8.7\end{array}$ & $\begin{array}{r}70.0 \\
22.1 \\
60.7 \\
3.3\end{array}$ & $\begin{array}{c}75.5^{*} \\
19.5 \\
53.6 \\
9.7\end{array}$ & $\begin{array}{c}89.7 * \\
35.0 \\
47.1 \\
7.9\end{array}$ & $\begin{array}{l}87.0^{*} \\
42.3 \\
47.1 \\
8.1\end{array}$ & $\begin{array}{c}75.8^{*} \\
20.8 \\
43.5 \\
8.9\end{array}$ & $\begin{array}{c}69.3^{*} \\
17.2 \\
39.5 \\
9.9\end{array}$ & $\begin{array}{r}76.4 \\
5.6 \\
75.0 \\
10.9\end{array}$ \\
\hline $\begin{array}{r}\text { SV } \\
(\mathrm{ml})\end{array}$ & $\begin{array}{l}\mathrm{D} \\
\mathrm{ND}\end{array}$ & $\begin{array}{r}1080.1 \\
138.4 \\
1028.3 \\
121.2\end{array}$ & $\begin{array}{l}969.9 \\
196.9 \\
894.2 \\
188.7\end{array}$ & $\begin{array}{r}776.6 \\
148.0 \\
820.2 \\
81.3\end{array}$ & $\begin{array}{c}1101.8^{*} \\
162.0 \\
763.8 \\
36.2\end{array}$ & $\begin{array}{c}1048.7 * \\
234.1 \\
700.6 \\
113.0\end{array}$ & $\begin{array}{c}1146.5^{*} \\
264.7 \\
653.1 \\
83.7\end{array}$ & $\begin{array}{c}1104.4^{*} \\
342.5 \\
644.5 \\
60.1\end{array}$ & $\begin{array}{c}993.1^{*} \\
194.7 \\
641.7 \\
98.0\end{array}$ & $\begin{array}{l}952.4^{*} \\
172.4 \\
590.5 \\
112.2\end{array}$ & $\begin{array}{r}1019.5 \\
66.9 \\
1066.8 \\
192.9\end{array}$ \\
\hline $\begin{array}{l}\text { TPR } \\
\left(\text { dyn } \cdot \mathrm{s} / \mathrm{cm}^{5)}\right.\end{array}$ & $\begin{array}{l}\mathrm{D} \\
\mathrm{ND}\end{array}$ & $\begin{array}{l}-{ }^{e)} \\
- \\
-\end{array}$ & $\begin{array}{r}206.7 \\
39.6 \\
190.9 \\
66.0\end{array}$ & $\begin{array}{r}127.9 \\
4.5 \\
120.0 \\
25.9\end{array}$ & $\begin{array}{r}170.0 \\
37.0 \\
131.3 \\
14.2\end{array}$ & $\begin{array}{r}153.3 \\
46.8 \\
140.4 \\
16.0\end{array}$ & $\begin{array}{r}150.2 \\
70.3 \\
194.7 \\
47.4\end{array}$ & $\begin{array}{r}152.8 \\
56.9 \\
204.3 \\
28.5\end{array}$ & $\begin{array}{r}169.7 \\
42.5 \\
220.9 \\
32.8\end{array}$ & $\begin{array}{r}172.0 \\
32.5 \\
225.5 \\
47.0\end{array}$ & $\begin{array}{r}231.5 \\
13.9 \\
240.0 \\
36.2\end{array}$ \\
\hline $\begin{array}{l}\text { UV } \\
(\mathrm{ml} / \mathrm{kg} / \mathrm{hr})\end{array}$ & $\begin{array}{l}\text { D } \\
\text { ND }\end{array}$ & $\begin{array}{l}- \\
- \\
-\end{array}$ & $\begin{array}{l}1.3 \\
1.3 \\
1.0 \\
0.8\end{array}$ & $\begin{array}{l}3.1 \\
2.2 \\
2.7 \\
2.7\end{array}$ & $\begin{array}{l}3.3 \\
2.9 \\
2.0 \\
1.8\end{array}$ & $\begin{array}{l}4.2 \\
3.7 \\
2.6 \\
1.9\end{array}$ & $\begin{array}{l}4.1 \\
4.7 \\
1.2 \\
1.4\end{array}$ & $\begin{array}{l}3.3^{*} \\
2.4 \\
1.0 \\
0.7\end{array}$ & $\begin{array}{l}2.0^{*} \\
0.8 \\
0.6 \\
0.4\end{array}$ & $\begin{array}{l}1.4^{*} \\
0.9 \\
0.3 \\
0.1\end{array}$ & $\begin{array}{l}- \\
- \\
-\end{array}$ \\
\hline
\end{tabular}

a) Spontaneous ventilation. b) Dobutamine infusion started after 30 minutes measurement. c) Data are expressed as mean. d) Data are expressed as standard deviation. e) Not done. *Significant difference between D and ND groups, $\mathrm{P}<0.05$.

differed significantly after 90 min or more. The values in the $\mathrm{D}$ group remained between 1.4 and $4.2 \mathrm{ml} / \mathrm{kg} / \mathrm{hr}$.

\section{Discussion}

Cardiovascular and respiratory depression has been described during inhalation anesthesia in dorsally recumbent horses $[8,9,27]$. Most of this depression can be related to the specific physiology and anatomy of the adult horse, in which mechanical forces lead to pulmonary cavity compression and changes in the ventilation-perfusion ratio [8, 9, 27]. Mizuno et al. [18] investigated the effects of dorsal recumbency on cardiovascular function during halothane anesthesia. They observed severe cardiovascular depression (the MABP decreased at 46.0 to $48.6 \mathrm{mmHg}$, the $\mathrm{CO}$ decreased at 25.7 to $26.5 \mathrm{ml} / \mathrm{kg} / \mathrm{min}$ and urine volume decreased at 0.2 to $0.3 \mathrm{ml} / \mathrm{kg} / \mathrm{hr}$ ) after $75 \mathrm{~min}$ or longer of anesthesia in dorsally recumbent horses.

Methods used for improving cardiovascular depression occurring during inhalation anesthesia in horses have included fluid infusions [22], dopamine [28, 29], dobutamine [28], isoproterenol
[12], and hypertonic saline solution [6].

In this study, dobutamine infusion was selected as the vasopressor for dorsally recumbent horses anesthetized with isoflurane, and the effect of this agent on the prevention cardiovascular depression were observed.

Dobutamine is a catecholamine which has been demonstrated to exert positive inotropic and slight chronotropic effects in humans and dogs $[13,15$, 32, 33]. However, development of atrioventricular (AV) block has been observed after dobutamine infusion in horses [4]. A pilot study to determine the effects of dobutamine on the HR, ECG and $\mathrm{ABP}$ in 4 standing resting horses was carried out. Bradycardia was observed in all the horses during the initial stage of dobutamine administration. The MABP increased to $150 \%$ of the premedicated value and one horse developed seconddegree AV block after increased of MABP with 2.0 $\mu \mathrm{g} / \mathrm{kg} / \mathrm{min}$ dobutamine [unpublished data]. In this study, the dobutamine infusion rate used was maintained below $2.0 \mu \mathrm{g} / \mathrm{kg} / \mathrm{min}$ in view of the results of the pilot study. The dobutamine infusion rate was adjusted in response to the $\mathrm{ABP}$ and HR changes. The level of the scapulohumeral joint was selected as the zero reference pressure point 

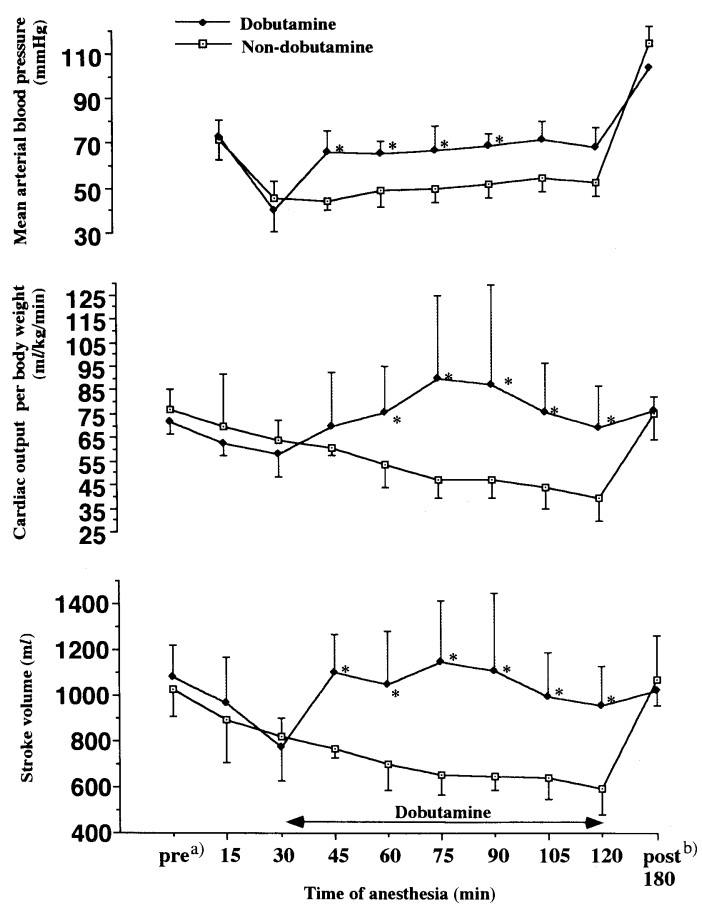

Fig. 1. Hemodynamic changes induced by dobutamine infusion in dorsally recumbent isoflurane-anesthetized horses.

a): The value from pre-anesthesia.

b): The value at $180 \mathrm{~min}$ after recovery from anesthesia.

* Significant difference between dobutamine group and non-dobutamine group; $\mathrm{P}<0.05$.

$\leftarrow$ Dobutamine infusion period.

for ABP measurement after affirmation of the position of the right atrium by echo-cardiography. In horses, it has been suggested that the MABP required to perfuse organs such as the heart, brain, and kidney is 65 to $70 \mathrm{mmHg}$ or more to prevent postoperative myopathy, lameness, and difficulty in standing $[10,16,21]$. In this study, the MABP in the D group was maintained slightly lower levels than the $70 \mathrm{mmHg}$ initially envisaged so that the dobutamine infusion rate could not be increased caused by increasing in HR after $75 \mathrm{~min}$ of anesthesia.

Dobutamine was infused at a rate of 0.51 to 1.23 (mean, 0.86 ) $\mu \mathrm{g} / \mathrm{kg} / \mathrm{min}$ in the D group. Donaldson [4] reported that $1.7 \mu \mathrm{g} / \mathrm{kg} / \mathrm{min}$ dobutamine increased the MABP by at least $10 \%$ during surgery in laterally and dorsally recumbent halothaneanesthetized horses. The D group's dobutamine dosage was lower than in his study, but the MABP increased by at least $30 \%$. This difference may be due to variations in preanesthetic status, due to the fact that the animals in Donaldson's study were clinical cases included acute abdominal conditions. Horses with severe colic subjected to abdominal surgery always show severe dehydration, which suggests that the circulatory system was already depressed before surgery [29]. Another explanation may be the different inhalation anesthetic used.

The HR tended to be higher than in the ND group, and to increase in the $\mathrm{D}$ group 75 min or more after a constant MABP value had been reached. The changes in HR showed individual differences, and these were responsible for the large standard deviation values for $\mathrm{CO}$ after 75 and 90 min of anesthesia in the $\mathrm{D}$ group. We have previously observed that halothane anesthesia combined with dobutamine infusion in dorsally recumbent horses did not increase the HR [18]. Also, it is well known that isoflurane itself increases $\mathrm{HR}$, in contrast to halothane $[2,7,26]$. These results suggest that the dobutamine infusion exerted a slight chronotropic effect as well as its major inotropic effect in isoflurane-anesthetized horses.

The CO in the D group was maintained at or above the preanesthetic level during the dobutamine infusion. This related to the increased stroke volume and $\mathrm{HR}$. The $\mathrm{CO}$ in the ND group tended to decrease with time (the lowest value observed was $39.5 \mathrm{ml} / \mathrm{kg} / \mathrm{min}$ ). This decrease appeared to be attributable to a diminished stroke volume, as a minor decrease in the HR was observed.

The urine volume is an indirect indicator of kidney perfusion [25]. A urine volume of at least 1 $\mathrm{ml} / \mathrm{kg} / \mathrm{hr}$ is the goal during anesthesia, in order to maintain normal renal function [11]. In this study, the urine volume in the ND group decreased to 1 $\mathrm{ml} / \mathrm{kg} / \mathrm{hr}$ or less after $90 \mathrm{~min}$ of anesthesia. This reflected a decrease in kidney perfusion caused by the decrease in $\mathrm{CO}$ and $\mathrm{ABP}$. The urine volume in the $\mathrm{D}$ group was maintained at 1.4 to $4.2 \mathrm{ml} / \mathrm{kg} / \mathrm{hr}$ which suggests that the peripheral perfusion of the kidney was adequate.

In humans, the $\mathrm{CO}$ value during anesthesia should be maintained as near as possible to the preanesthetic value to ensure adequate perfusion of the major organs [1]. The $\mathrm{CO}$ and urine volume in the $\mathrm{D}$ group were maintained at adequate levels in this study, showing that management of these parameters during anesthesia can maintain cardiovascular function at safe levels such as those 
suggested above.

In this study, various cardiovascular parameters, such as $\mathrm{ABP}, \mathrm{CO}$, and urine volume, could be maintained by administering an IV infusion of dobutamine. The infusion was not associated with any postanesthetic complications. These observations suggest that dobutamine is useful for preventing cardiovascular depression in isofluraneanesthetized, dorsally recumbent horses. This finding is of major importance for horses undergoing surgery for colic and other procedures requiring inhalation anesthesia in dorsal recumbency.

\section{References}

1. Bushman, J.A., Mangano, D.T., and Nunn, J.F. 1989. Monitoring during anesthesia. pp. 463-492. In: General anesthesia, 5th ed. (Nunn, J. F. ed.), Butterworths, London.

2. Cahalan, M.K., Lurz, F.W., Beaupre, P.N., Schwartz, L.A., and Eger, E.I. 1983. Narcotics alter the heart rate and blood pressure response to inhalational anesthetics. Anesthesiology 59: A26.

3. Daunt, D.A. 1990. Supportive therapy in the anesthetized horse. The Vet. Clinics of North Am. Equine Practice. 6: 557-574.

4. Donaldson, L. 1988. Retrospective assessment of dobutamine therapy for hypotension in anesthetized horses. Vet. Surg. 17: 53-57.

5. Dunlop, C.I., Steffey, E.P., Miller, M.F., and Woliner, M.J. 1987. Temporal effects of halothane and isoflurane in laterally recumbent ventilated male horses. Am. J. Vet. Res. 48: 1250-1255.

6. Dyson, D.H., and Paschoe, P.J. 1990. Influence of preinduction methoxamine, lactated Ringer solution, or hypertonic saline solution infusion on anesthetic-induced hypotension in horses. $A m$. J. Vet. Res. 51: 17-21.

7. Eger, E.I., Smith, N.T., Stoelting, R.K., Cullen, D.J., Nadis, L.B., and Whitcher, C.E. 1970. Cardiovascular effects of halothane in man. Anesthesiology 32: 396-409.

8. Gasthuys, F., Moor, A., and Parmentier, D. 1991. Hemodynamic effects of change in position and respiration mode during a standard halothane anesthesia in ponies. J. Vet. Med. A. 38: 203-211.

9. Gleed, R.D., and Dobson, A. 1988. Improvement in arterial oxygen tension with change in posture in anesthetized horses. Res. Vet. Sci. 44: 255-259.

10. Grandy, J.L., Steffey, E.P., Hodgson, D.S., and Woliner, M.J. 1987. Arterial hypotension and the development of postanesthetic myopathy in halothane-anesthetized horses. Am. J. Vet. Res. 48:
192-197.

11. Haskins, S.C. 1987. Monitoring the anesthetized patient. pp. 455-477. In: Principles \& Practice of Veterinary Anesthesia (Short, C.E. ed.). Williams \& Wilkins, Baltimore.

12. Klein, L. 1982. Anesthetic emergencies. pp. 282300. In: Equine Medicine and Surgery, 3rd ed. (Mansmann, R.A. ed.), American Veterinary Publications, Santa Barbara.

13. Kubota, M., Taketani, N., Hojo, Y., Odagiri, M., Igarashi, M., Takeda, R., Imai, T., and Goto, Y. 1986. Effects of dobutamine in patients with hypotension during epidural or spinal anesthesia. Jpn. Pharmacol. Therapeutics 14: 3493-3500 (in Japanese).

14. Lindsay, W.A., Robinson, G.M., Brunson, D.B., and Majors, L.J. 1989. Induction of equine postanesthetic myositis after halothane-induced hypotension. Am. J. Vet. Res. 50: 1154-1 160.

15. Matumura, S., Morishige, E., Uno, O., and Ueda, M. 1980. Comparative studies on the hemodynamic effects of dobutamine, dopamine, and isoproterenol in dogs in experimental shock. Folia Pharmacol. Japon 76: 131-141 (in Japanese).

16. McDonell, W.N., and Doris, H.D. 1990. Monitoring the anesthetized horse. pp. 87-93. In: Current Practice of Equine Surgery (Whight, N.A. and Moore, J.N. eds), J.B. Lippincott Company, Philadelphia.

17. Mizuno, Y., Aida, H., and Hara, H. 1993. Usefulness of intermittent positive pressure ventilation for improving respiratory depression during anesthesia in dorsally recumbent horse. Jpn. J. Vet. Anesth. Surg. 24: 27-33 (in Japanese).

18. Mizuno, Y., Aida, H., and Hara, H. 1993. Cardiovascular effect of dorsal recumbency and dobutamine infusion in halothane anesthesia of horses. Jpn. J. Vet. Anesth. Surg. 24: 65-73 (in Japanese).

19. Mizuno, Y., Aida, H., Hara, H., and Fujinaga, T. 1994. Cardiovascular effects of intermittent positive pressure ventilation in the anesthetized horses. J. Vet. Med. Sci. 56: 39-44.

20. Mizuno, Y., Aida, H., Hara, H., Fujinaga, T., and Hagio, M. 1994. Comparison of methods of cardiac output measurements determined by dye dilution, pulsed Doppler echocardiography and thermodilution in horses. J. Vet. Med. Sci. 56: 1-5.

21. Muir, W.W. 1989. Hemodynamic monitoring. pp. 173-190. In: Handbook of Veterinary Anesthesia (Muir, W.W. and Hubbell, J.A. eds), C.V. Mosby Company, St. Louis.

22. Raffe, M.R. 1987. Fluid therapy, electrolyte and acid-balance, and blood replacement. pp. 478-516. In: Principles \& Practice of Veterinary Anesthesia (Short, C.E. ed.), Williams \& Wilkins, Baltimore.

23. Serteyn, D., Mettart, E., and Michaux, C. 1986. Laser Doppler flowmetry: Muscular microcircula- 
tion in anesthetized horses. Equine Vet. J. 18: 391395.

24. Serteyn, D., Coppens, P., Mettart, E., Micheket, S., Micheels, J., Philippart, C., and Lamy, M. 1987. Measurements of muscular microcirculation by laser Doppler flowmetry in isoflurane and halothane anesthetized horses. Vet. Rec. 121: 324-326.

25. Shimada, Y. 1991. ICU and CCU. pp. 281-296. In: New Anesthesiology, 3rd ed. (Takahashi, N. ed.), Nanzando, Tokyo (in Japanese).

26. Steffey, E.P., and Howland, D. 1980. Comparison of circulatory and respiratory effects of isoflurane and halothane anesthesia in horses. Am. J. Vet. Res. 41: 821-825.

27. Steffey, E.P., Wheat, J.D., Meagher, D.M., Norrie, R.D., Mckee, J., Brown, M., and Arnold, J. 1977. Body position and mode of ventilation influence arterial $\mathrm{pH}$, oxygen, and carbon dioxide tensions in halothane-anesthetized horses. Am. J. Vet. Res. 38: 379-382.

28. Swanson, C.R., Muir, W.W., Bendnarski, R.M., Skarda, R.T., and Hubbell, J.E. 1985. Hemo- dynamic responses in halothane-anesthetized horses given infusion of dopamine or dobutamine. Am. J. Vet. Res. 46: 365-370.

29. Trim, C.M. 1977. Anesthetic management of the horse with acute intestinal obstruction. Proc. Assoc. Vet. Anesth. 7: 28-41.

30. Tsuda, H., Niisato, Y., Hoshiko, T., Takeuchi, M., Yamada, T., Tokuyasu, M., Tutui, S., Takamoto, T., and Muteki, G. 1978. A hemodynamic study on new catecholamine-Dobutamine-. Jpn. Pharmacol. Ther. 6: 2297-2306 (in Japanese).

31. Tuttle, R.R., and Mills, J. 1975. Dobutamine. Development of new catecholamine to selectively increase cardiac contractility. Circ. Res. 36: 185196.

32. Ueda, M., Matsumura, S., Morishige, E., and Uno, I. 1978. Comparative studies on the systemic and regional hemodynamic effects of dobutamine and other catecholamines in dogs. Pharmacometolics 16: 327-335 (in Japanese).

33. Vatner, S. F., and McRitchie, R.J. 1974. Dobutamine, a new beta agonist. Anes. Analg. 53: 616-623. 